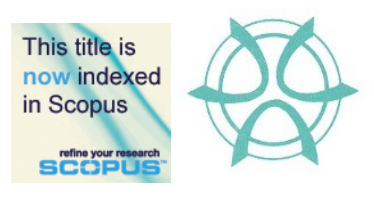

\title{
LAND CONVERSION PROCESSES AND LOCAL COMMUNITY ASSESSMENT IN THE DISTRICT OF PETALING
}

\author{
Liyana Zainudin ${ }^{1}$, Zaharah Mohd Yusoff ${ }^{2}$, Saiful Aman Sulaiman ${ }^{3}$, Jaiya \\ $\mathrm{Abu}^{4}$ \\ ${ }^{1,2,3}$ Faculty of Architecture, Planning and Surveying \\ UNIVERSITI TEKNOLOGI MARA, MALAYSIA \\ ${ }^{4}$ Department of Director General of Lands and Mines \\ MALAYSIA
}

\begin{abstract}
Land use planning is part and parcel of both land development and town planning. In Malaysia, these two areas are steered independently, the former by a state or district's land office and the latter by the state's local authority. This study looks at the aspects of land development where land use conversion plays a crucial part, where it brings significance to land revenue. As the leading district in Malaysia, the district of Petaling is undeniably the busiest land office in the nation, working hand-in-hand with three city councils. Land premium that is imposed on approved applications for land use conversion has been one of the main contributors to the district and state's revenue as a whole. Given the hefty charges that have been imposed by the consultants for land use conversions, it is found that the application charges that are imposed by the land office are minimal. An assessment study on land conversion has been conducted and the result shows that the local community assessment score on familiarity, collectively stands at only $40 \%$. It is recommended that an awareness on land use as basic knowledge should be given priority as it may contribute to more efficient land development and town planning, as a whole.
\end{abstract}

Keywords: Land conversion, land use planning, land premium

\footnotetext{
${ }^{2}$ Associate Professor at Universiti Teknologi MARA. Corresponding email: zmy1208@uitm.edu.my
} 
Liyana Zainudin, Zaharah Mohd Yusoff, Saiful Aman Sulaiman, Jaiya Abu

Land Conversion Processes and Local Community Assessment in The District of Petaling

\section{INTRODUCTION}

One of the key performance indexes for a district is the revenue that it generates annually. According to the National Auditor General Report 2019 (Laporan Ketua Audit Negara 2019), the state of Selangor has been generating hundreds of millions to billions of incomes every year and the district of Petaling has been a top contributor to the state (National Auditor Department, 2019). The two main revenue collections come from the payment of land premium and quit rent, which is also known as land tax. It is significant to note that about $70 \%$ from the collections come from the payment of land premium. Land premium is collected upon the approval of land matters that include land use conversion and extension of lease. These land matters are crucial in terms of land development which supports town planning. Both land use conversion and expansionary zoning are one of the main sources of fiscal revenue for a local government (Hortas-Rico \& Gómez-Antonio, 2020).

The economical urban land in turn helps to boost the local government's revenue through transactions and tax impositions (Chen et al., 2018). It is a challenging process, given the fact that it requires land use changes in order to achieve urban growth (Briassoulis, 2008; Hillier, 2007; McNeill et al., 2014; Wong \& Watkins, 2009; Hersperger et al., 2020). Land use will have to change in order to accommodate social demands, and the ability of the authorities to cater to these changes through its existing policies will most likely hinder land use contradictions (Tian et al., 2020). Seeing the importance of land use and land use conversion in the aspects of town planning and land revenue generation, this study is conducted to share knowledge on the procedures and fees that are imposed in regards to land use conversion. For the purpose of understanding the procedures and how it relates to the statistics of land conversion processes, the selected case study area has been narrowed down to the district of Petaling, where a local community assessment study has been conducted and discussed in the research finding section.

\section{LAND USE CONVERSION IN THE NLC 1965}

Land conversion is initiated through an application by the land proprietor or through the power of attorney with the intentions to vary the existing use of land for an activity that conforms to the land title's express condition. In other words, and as an example, a land proprietor shall apply for a variation of category and or express condition of the land from 'Agriculture' to 'Residential Building' in order to have a house(s) built on an existing land for agricultural use. Referring to Section 52 of the National Land Code 1965 (NLC), there are three categories of land use, they are (i) Agriculture; (ii) Building; and (iii) Industrial. The specifics of the activities that are allowed as per land use is provisioned within Section 120 of the NLC, where the State Authority may impose express conditions and restrictions in interest. Through this provision, the Selangor Lands 
and Mines Office (PTGS) with the State Authority's approval, has released a circular that is known as Pekeliling PTG. Sel. 4/98 (Selangor Lands and Mines Office, 1998) which entails further types of activities that are allowed for each land use category and its express condition. It is also to be noted that through this circular, the land use category of 'Building' is divided into four sub-categories, which are (i) Residential; (ii) Commercial; (iii) Infrastructure; and (iv)Multipurpose. Therefore, referring to the earlier given example, a land proprietor shall vary the land use category and express condition for the purpose of building a home as follows:

$\begin{array}{ccc}\begin{array}{c}\text { Land Use Category: } \\ \text { Agriculture }\end{array} & \rightarrow & \begin{array}{c}\text { New Land Use Category: } \\ \text { Building }\end{array} \\ \begin{array}{c}\text { Express Condition: } \\ \text { General agriculture }\end{array} & \rightarrow & \text { New Express Condition: }\end{array}$

Land conversion may be applied through the various provisions within the NLC. The variety of provisions is due to reasons such as the type of land title, either a Qualified Title (QT) or a Final Title (FT), and the final outcome of a land title that the land proprietor intends to have. However, there is a slight difference in the provision that is stated within the S.204D's reference document (Pejabat Daerah dan Tanah Petaling, 2019a) where it has been stated as S.204B, instead of 204D as per NLC's provisions. According to the Selangor Lands and Mines Office who provides the guidelines for all the land offices in Selangor, S.204B is used as it refers to the approving power and not the provision in regards to an application. Additionally, in the state of Selangor, the two provisions of S.197 and S.76 of the NLC are also being used for land conversion. The difference in S.204D and S.197 \& S.76 is that the former 'guarantees' ownership of land to the original proprietor(s) with the proposed land conversion as per the approved planning permission. As for the latter, S.197 is an act of surrendering the land as a whole to the State Authority, and proposing a fresh alienation to whoever in accordance to the proprietor(s) wishes, and as according to the approved planning permission.

In terms of land conversion, both provisions of S.197 and S.76 are proposed to the State Authority for approval, but are subjected to terms, conditions and or any other decisions that the State Authority sees and deems as fitting. S.197 and 76 also help to accommodate the situation when a land title is still in QT status and does not have a Certified Plan as of the date of application, compared to S.204D which requires a QT-status land title to be supported with a Certified Plan upon submission. Table 1 is a summary of the land conversion provisions, some of the key requirements and or factors that are affecting the 
Liyana Zainudin, Zaharah Mohd Yusoff, Saiful Aman Sulaiman, Jaiya Abu

Land Conversion Processes and Local Community Assessment in The District of Petaling

application and the application fees that have been imposed based on the Selangor Land Rules 2003 and Selangor Quarry Rules 2003.

Table 1: NLC Provisions in regards to Land Conversion and its Key Requirements

\begin{tabular}{|c|c|c|c|c|c|}
\hline \multirow{2}{*}{ No. } & \multirow{2}{*}{$\begin{array}{l}\text { Provision } \\
\text { (Section in } \\
\text { NLC) }\end{array}$} & \multicolumn{2}{|r|}{ Requirements } & \multirow[t]{2}{*}{ Land matters allowed } & \multirow{2}{*}{$\begin{array}{c}\text { Application } \\
\text { Fee (based } \\
\text { on SLR) } \\
\end{array}$} \\
\hline & & $\begin{array}{c}\text { Land } \\
\text { Title }\end{array}$ & Proprietorship & & \\
\hline 1. & S.124A & FT & $\begin{array}{l}\text { Only same } \\
\text { proprietors for each } \\
\text { land in submission }\end{array}$ & $\begin{array}{l}\text { Simultaneous subdivision } \\
\text { and vary condition }\end{array}$ & $\begin{array}{l}\text { Between } \\
\text { RM120 to } \\
\text { RM600 }\end{array}$ \\
\hline 2. & $\begin{array}{l}\text { S. } 124(1) \\
\text { (a) \& (c) }\end{array}$ & $\begin{array}{l}\text { QT or } \\
\text { FT }\end{array}$ & $\begin{array}{l}\text { Only same } \\
\text { proprietors for each } \\
\text { land in submission }\end{array}$ & $\begin{array}{l}\text { Vary category and } \\
\text { express condition }\end{array}$ & \multirow{2}{*}{$\begin{array}{l}\text { Between } \\
\text { RM70 to } \\
\text { RM140 }\end{array}$} \\
\hline 3. & $\begin{array}{l}\text { S.124(1) } \\
\text { (c) }\end{array}$ & $\begin{array}{l}\text { QT or } \\
\text { FT }\end{array}$ & $\begin{array}{l}\text { Only same } \\
\text { proprietors for each } \\
\text { land in submission }\end{array}$ & Amend express condition & \\
\hline 4. & S.204D & FT & $\begin{array}{l}\text { Only same } \\
\text { proprietors for each } \\
\text { related land in } \\
\text { submission }\end{array}$ & $\begin{array}{l}\text { Simultaneous subdivision, } \\
\text { amalgamation, vary } \\
\text { condition, lease extension }\end{array}$ & $\begin{array}{l}\text { Between } \\
\text { RM50 to } \\
\text { RM200 }\end{array}$ \\
\hline \multicolumn{6}{|c|}{ Additional administrative provision in Selangor: } \\
\hline 5. & $\begin{array}{l}\text { S. } 197 \& \\
\text { S. } 76\end{array}$ & $\begin{array}{l}\text { QT or } \\
\text { FT }\end{array}$ & $\begin{array}{l}\text { May have } \geq 1 \\
\text { proprietor } \& \\
\text { multiple land in } \\
\text { submission }\end{array}$ & $\begin{array}{l}\text { Simultaneous subdivision, } \\
\text { amalgamation, vary } \\
\text { condition, lease extension, } \\
\text { change proprietorship } \\
\text { (upon land alienation) }\end{array}$ & $\begin{array}{l}\text { Between } \\
\text { RM50 to } \\
\text { RM300 }\end{array}$ \\
\hline
\end{tabular}

\section{THE PROCESS AND STANDARD PROCEDURES}

For the purpose of a simplified and brief explanation, these are the steps in land use conversion of the approved applications:

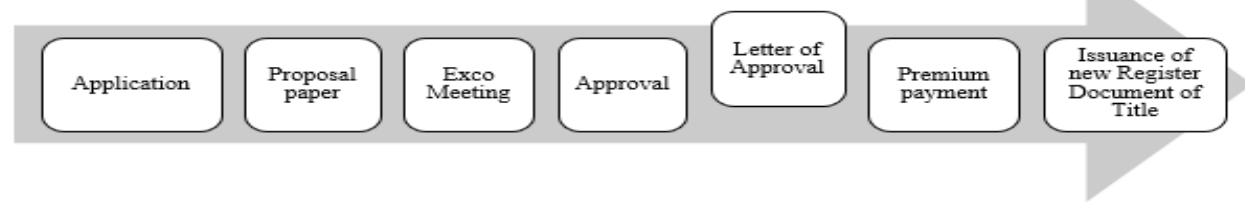

Diagram 1: Land Use Conversion Process

Table 2 is a summary of some of the key requirements for each application. Highlighted here is the 'Approved Planning Permission' in which has been issued by Local Authorities (LA) through the provisions of S.22 of the 
Town and Country Planning Act 1976. The role of LA was described in Subsection 5(1); where LA shall act as a Local Planning Authority (LPA) and are responsible in controlling the development of land, building, industry and any related public places matters within their respective administrative area. (Yusup et.al, 2018; Lim S. et.al, 2017).

Table 2: NLC Provisions in regards to Land Conversion and its Key Requirements

\begin{tabular}{|c|c|c|c|c|c|}
\hline \multirow{2}{*}{ No. } & \multirow{2}{*}{$\begin{array}{c}\text { Provision } \\
\text { (Section in } \\
\text { NLC) }\end{array}$} & $\begin{array}{c}\text { LAND } \\
\text { TITLE }\end{array}$ & Proprietorship & Document & Reference \\
\cline { 3 - 5 } & S.124A & FT & $\begin{array}{c}\text { Only same } \\
\text { proprietors for each } \\
\text { land in submission }\end{array}$ & $\begin{array}{c}\text { Approved Planning } \\
\text { Permission }\end{array}$ & $\begin{array}{c}\text { (Pejabat Daerah } \\
\text { dan Tanah } \\
\text { Petaling, 2019c) }\end{array}$ \\
\hline 2. & $\begin{array}{c}\text { S.124(1)(a) } \\
\&(\mathrm{c})\end{array}$ & $\begin{array}{c}\text { QT or } \\
\text { FT }\end{array}$ & $\begin{array}{c}\text { Only same } \\
\text { proprietors for each } \\
\text { land in submission }\end{array}$ & 'Kembaran A'* & (Pejabat Daerah \\
dan Tanah \\
3.
\end{tabular}

*Kembaran 'A' is a declaration form of land condition and use by applicant, for the verification of land office's Settlement Officer

\section{RESEARCH METHODOLOGY}

This study uses positivist method and causal-comparative research design (Chua, 2020) to explore the relationship between variables that are relevant to the study. Accordingly, the total sample size is 400 which is derived using Slovin's Formula with 5\% sampling error and 95\% confidence level. Due to the COVID-19 pandemic, a large population number, i.e., hundreds of respondents were needed, hence a Snowball sampling technique was used for the purpose of distribution, channelled through the WhatsApp mobile application. A set of Google Form questionnaire, with straight-forward single-select multiple-choice and 'yes' or 'no' questions, was distributed over a period of two months and a total of 500 people had responded. However, only 434 relevant respondents were applicable to this study. Correspondingly, Diagram 2 shows the overall research methodology. 
Liyana Zainudin, Zaharah Mohd Yusoff, Saiful Aman Sulaiman, Jaiya Abu

Land Conversion Processes and Local Community Assessment in The District of Petaling

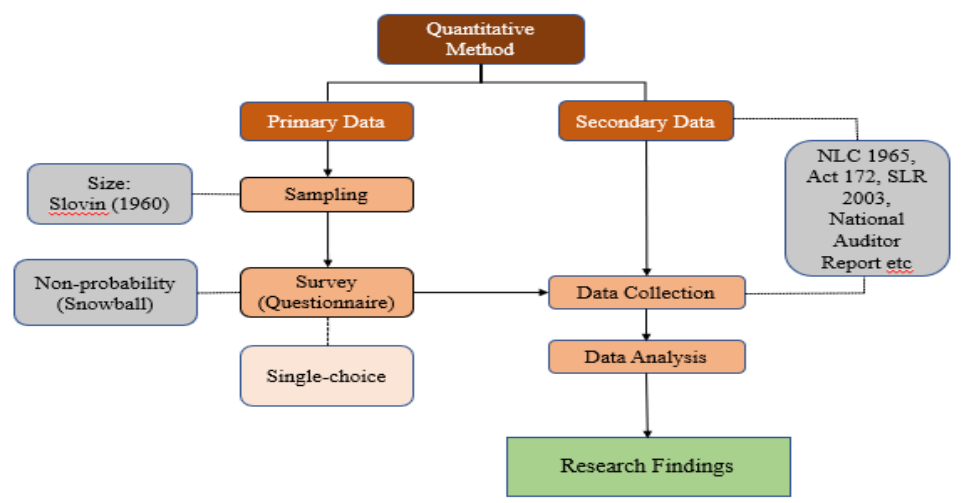

Diagram 2: Research Methodology Flowchart

\section{CASE STUDY AREA}

The district of Petaling is located in the state of Selangor, with an area of 486.99 kilometre $^{2}$ and makes up to about $6 \%$ of the state. Ranking at the top of the list for district performance in Malaysia, Petaling is also the most populated district with a population of 2.19 million residents. The district's residents per se represents $11.6 \%$ of the Malaysian population. Diagram 3 show the four main parish in Petaling Distict.

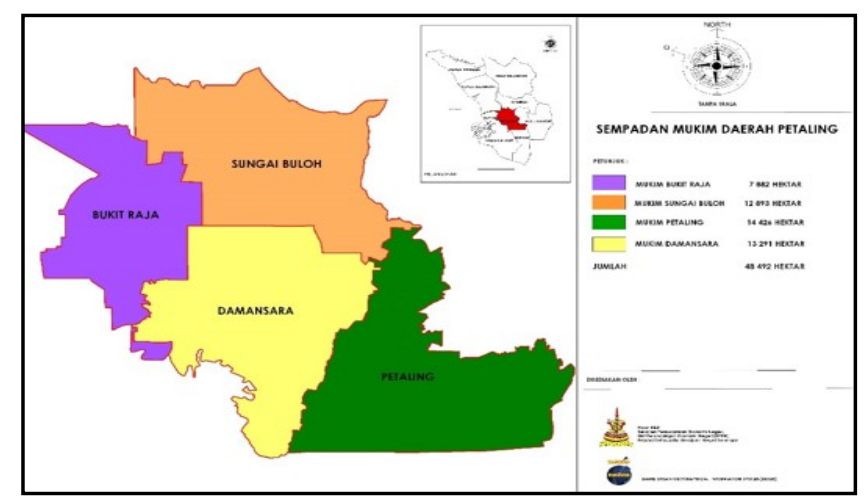

Diagram 3: The four main parish (mukim) in Petaling district Source: Petaling District and Land Office's Official Website via https://www.selangor.gov.my/petaling.php/pages/view/27? mid=114

\section{LAND CONVERSION STATISTICS IN PETALING}

This section shows the reality of the land conversion applications, whether or not every application has been processed, approved and or paid. It is significant to understand these facts as the effects shall be explained in the following section. 
Based on Table 3, one application has been rejected due to the failure to fulfil the application requirement as is stated within the provisions of S.203(1) of the NLC, where the application has not been made by the same set of proprietors of each adjoining land.

Table 3: Statistics of Land Conversion Application in Petaling District for year 2018, 2019 and 2020

\begin{tabular}{|c|c|c|c|c|c|c|c|c|c|c|c|c|c|}
\hline No & $\begin{array}{c}\text { Land } \\
\text { Matter } \\
\text { (Section in } \\
\text { NLC) }\end{array}$ & \multicolumn{3}{|c|}{ No. of application } & \multicolumn{3}{|c|}{ Approved } & \multicolumn{3}{|c|}{ Rejected } & \multicolumn{3}{|c|}{$\begin{array}{c}\text { Payment } \\
\text { settlement (no. of } \\
\text { applicant paid) }\end{array}$} \\
\hline \multicolumn{2}{|r|}{ YEAR } & '18 & '19 & '20 & ' 18 & ' 19 & '20 & '18 & '19 & '20 & ' 18 & '19 & '20 \\
\hline 1. & S.124A & 1 & 1 & 0 & 1 & 1 & 0 & 0 & 0 & 0 & 1 & 1 & 0 \\
\hline 2. & $\begin{array}{l}\text { S.124(1)(a) } \\
\&(c)\end{array}$ & 35 & 36 & 17 & 32 & 21 & 5 & 0 & 0 & 0 & 18 & 18 & 5 \\
\hline 3. & S.124(1)(c) & 0 & 10 & 4 & 0 & 3 & 2 & 0 & 0 & 0 & 0 & 2 & 2 \\
\hline 4. & S.204D & 51 & 33 & 12 & 27 & 24 & 1 & 1 & 1 & 1 & 17 & 22 & 1 \\
\hline 5. & $\begin{array}{l}\text { S. } 197 \text { and } \\
\text { S. } 76\end{array}$ & 15 & 18 & 13 & 12 & 8 & 3 & 0 & 0 & 0 & 8 & 6 & 3 \\
\hline & Total & 102 & 98 & 46 & 72 & 57 & 11 & 1 & 1 & 1 & 44 & 49 & 11 \\
\hline
\end{tabular}

Other than that, the applicant of S.204D has been rejected due to land use for Limited Commercial purposes, which does not exist within any land use category as per Pekeliling Pengarah Tanah dan Galian Bil. 4/98 (Selangor Lands and Mines Office, 1998). Furthermore, the application has been rejected under S.204D due to the failure of getting the signature of one of the land proprietors, who has died and has not nominated any executor nor land administrator on his behalf. In summary, when applications are, (i) Rejected or (ii) Still in process, the land use shall remain the same and may be subjected to enforcement. For applications that have been accepted and that are still in process, enforcement measures on contradicting land use may be withdrawn temporarily as applications have been endorsed on the land title, thus giving proof that land use change is already in process.

\section{DUE PAYMENT AND FAILURES ON FULL SETTLEMENT}

Upon approval from the State Authority and notice, the applicant shall settle in full all premium payment that is due for land conversion. The date of effect starts from the day when the notice of payment for Form $5 \mathrm{~A}$ or $7 \mathrm{G}$ has been served. Referring to the Selangor Lands and Mines Office Circular No. 1/2016 (Pekeliling Pengarah Tanah dan Galian Selangor Bil 1/2016) (Selangor Lands and Mines Office, 2016), no staggered or instalment-like payment is allowed, and the period of payment in full is as per Table 4 below: 
Liyana Zainudin, Zaharah Mohd Yusoff, Saiful Aman Sulaiman, Jaiya Abu

Land Conversion Processes and Local Community Assessment in The District of Petaling

Table 4: Period of Payment for each land conversion type according to Section in National Land Code 1965

\begin{tabular}{|c|c|c|c|c|c|c|c|}
\hline No. & $\begin{array}{c}\text { Land } \\
\text { Matter } \\
\text { (Section } \\
\text { in NLC) }\end{array}$ & $\begin{array}{l}\text { Notice } \\
\text { (Form) }\end{array}$ & $\begin{array}{c}\text { Initial } \\
\text { payment } \\
\text { period }\end{array}$ & $\begin{array}{c}1^{\text {st }} \text { Payment } \\
\text { extension (as } \\
\text { per official } \\
\text { application) }\end{array}$ & $\begin{array}{l}2^{\text {nd }} \text { Payment } \\
\text { extension (as } \\
\text { per official } \\
\text { application) }\end{array}$ & $\begin{array}{c}3^{\text {rd }} \\
\text { Payment } \\
\text { extension } \\
\text { with } \\
\text { additional } \\
\text { charge (\%) } \\
\text { of } \\
\text { premium }\end{array}$ & $\begin{array}{c}\text { Total } \\
\text { payment } \\
\text { period }\end{array}$ \\
\hline 1. & S.124A & $7 \mathrm{G}$ & 3 months & 3 months & 1 month & $3 \%$ & 7 months \\
\hline 2. & $\begin{array}{l}\text { S.124(1) } \\
\text { (a) \& (c) }\end{array}$ & $7 \mathrm{G}$ & 3 months & 3 months & 1 month & $3 \%$ & 7 months \\
\hline 3. & $\begin{array}{c}\text { S.124(1) } \\
(\mathrm{c})\end{array}$ & $7 \mathrm{G}$ & 3 months & 1 months & 1 month & $3 \%$ & 7 months \\
\hline 4. & S.204D & $5 \mathrm{~A}$ & 6 months & 6 months & Not allowed & $\begin{array}{c}\text { Not } \\
\text { applicable }\end{array}$ & $\begin{array}{c}12 \\
\text { months }\end{array}$ \\
\hline 5. & $\begin{array}{l}\text { S.197 and } \\
\text { S.76 }\end{array}$ & $5 \mathrm{~A}$ & 6 months & 6 months & Not allowed & $\begin{array}{c}\text { Not } \\
\text { applicable }\end{array}$ & $\begin{array}{c}12 \\
\text { months }\end{array}$ \\
\hline
\end{tabular}

Premium rates for land conversion are as per Table 5. The failure to settle the land premium will lead to an annulled land use conversion approval, hence the land use remains the same. If a land proprietor decides to continue with the intended development or existing land use which does not conform to its express condition, the land proprietor shall be charged with a breach of condition under S.125 of the NLC, which may lead to land forfeiture under the provision of S.130 of NLC, if the issue is not remedied within the given time.

Table 5: Premium rate for each land conversion type according to Selangor Land Rules 2003 \& Selangor Quarry Rules 2003

\begin{tabular}{|c|c|c|}
\hline $\begin{array}{c}\text { Initial Land } \\
\text { Use }\end{array}$ & $\begin{array}{c}\text { Approved Land } \\
\text { Use }\end{array}$ & Rate of payment (Calculation Formula) \\
\hline \multirow[t]{3}{*}{ Agriculture } & Residential & $15 \%$ of current land value $\mathrm{x}$ land area (in metre ${ }^{2}$ ) \\
\hline & Industry & $\begin{array}{c}\text { Light Industry: } 20 \% \\
\text { Medium Industry: } 25 \% \\
\text { Heavy Industry: } 30 \% \\
\text { of current land value x land area }\left(\text { in } \text { metre }^{2} \text { ) }\right.\end{array}$ \\
\hline & Commercial & $30 \%$ of current land value $\mathrm{x}$ land area (in metre ${ }^{2}$ ) \\
\hline \multirow[t]{2}{*}{ Residential } & Agriculture & Not applicable \\
\hline & Industry & $\begin{array}{l}\text { Light Industry: } 15 \% \\
\text { Medium Industry: } 10 \% \\
\text { Heavy Industry: } 15 \%\end{array}$ \\
\hline
\end{tabular}


PLANNING MALAYSIA

Journal of the Malaysia Institute of Planners (2021)

\begin{tabular}{|c|c|c|}
\hline $\begin{array}{c}\text { Initial Land } \\
\text { Use }\end{array}$ & $\begin{array}{c}\text { Approved Land } \\
\text { Use }\end{array}$ & Rate of payment (Calculation Formula) \\
\hline \multirow{3}{*}{ Industry } & Agriculture & of current land value $x$ land area (in metre $^{2}$ ) \\
\cline { 2 - 3 } & Commercial & $15 \%$ of current land value $x$ land area (in metre $^{2}$ ) \\
\cline { 2 - 3 } & Residential & Not applicable \\
\cline { 2 - 3 } & Commercial & $10 \%$ of current land value x land area (in metre $\left.{ }^{2}\right)$ \\
\hline \multirow{2}{*}{ Commercial } & Agriculture & Not applicable \\
\cline { 2 - 3 } & Industry & RM100.00 (Nominal) per title \\
\cline { 2 - 3 } & Residential & RM100.00 (Nominal) per title \\
\hline
\end{tabular}

\section{RESEARCH FINDINGS}

In regards to contradicting land use and a breach of condition under S.125 of the NLC, an assessment was conducted on the local community of Selangor in terms of land use conversion. The reason for the expansion of the area of study is to gain an overall view, as policies that have been implemented have not been focused down to district-level but have been implemented state-wide. Table 6 shows the results of the local community assessment on land use conversion. It is concluded that only $80.8 \%$ of those who are employed and who are aged between 21 and 50 have seen a land title, yet only half of these respondents are familiar with land conversion. Although this group of respondents has scored the highest in terms of familiarity on land conversion, only $8.5 \%$ have actually submitted an application for land conversion, while almost half of them feels that the premium that has been imposed is high.

Table 6: Results of study of local community assessment on land use conversion

\begin{tabular}{|c|c|c|c|c|c|c|c|c|}
\hline Subject & $\begin{array}{l}\text { Employe } \\
\text { d } \\
\text { (Age } 21 \\
\text { and } \\
\text { above) } \\
\end{array}$ & $\%$ & $\begin{array}{l}\text { Unemploye } \\
\text { d } \\
\text { (Age } 21 \text { to } \\
50)\end{array}$ & $\%$ & $\begin{array}{l}\text { Unemploy } \\
\text { ed } \\
\text { (Age } 51 \text { \& } \\
\text { above) }\end{array}$ & $\%$ & $\begin{array}{l}\text { To } \\
\text { tal }\end{array}$ & $\%$ \\
\hline $\begin{array}{l}\text { Seen a } \\
\text { Register } \\
\text { Document of } \\
\text { Title } \\
\end{array}$ & 286 & 80.8 & 21 & $\begin{array}{c}61 . \\
8\end{array}$ & 34 & $\begin{array}{c}73 . \\
9\end{array}$ & $\begin{array}{c}34 \\
1\end{array}$ & 78.6 \\
\hline $\begin{array}{l}\text { Familiar } \\
\text { with land } \\
\text { conversion } \\
\end{array}$ & 183 & 51.7 & 8 & $\begin{array}{c}23 \\
5\end{array}$ & 21 & $\begin{array}{c}45 . \\
7\end{array}$ & $\begin{array}{c}21 \\
2\end{array}$ & 48.8 \\
\hline $\begin{array}{l}\text { Submitted } \\
\text { an } \\
\text { application }\end{array}$ & 30 & 8.5 & 1 & 2.9 & 6 & $\begin{array}{c}13 . \\
0\end{array}$ & 37 & 8.5 \\
\hline
\end{tabular}


Liyana Zainudin, Zaharah Mohd Yusoff, Saiful Aman Sulaiman, Jaiya Abu

Land Conversion Processes and Local Community Assessment in The District of Petaling

\begin{tabular}{|c|c|c|c|c|c|c|c|c|}
\hline Subject & $\begin{array}{c}\text { Employe } \\
\text { d } \\
\text { (Age 21 } \\
\text { and } \\
\text { above) }\end{array}$ & $\%$ & $\begin{array}{c}\text { Unemploye } \\
\text { d } \\
\text { (Age } 21 \text { to } \\
50)\end{array}$ & $\%$ & $\begin{array}{c}\text { Unemploy } \\
\text { ed } \\
\text { (Age } 51 \& \\
\text { above) }\end{array}$ & $\%$ & $\begin{array}{l}\text { To } \\
\text { tal }\end{array}$ & $\%$ \\
\hline \multicolumn{9}{|l|}{$\begin{array}{l}\text { for land } \\
\text { conversion }\end{array}$} \\
\hline $\begin{array}{l}\text { Aware of the } \\
\text { imposition of } \\
\text { Further } \\
\text { Premium } \\
\text { upon } \\
\text { approval }\end{array}$ & 140 & 39.5 & 6 & $\begin{array}{c}17 . \\
6\end{array}$ & 15 & $\begin{array}{c}32 . \\
6\end{array}$ & $\begin{array}{c}16 \\
1\end{array}$ & 37.1 \\
\hline \multicolumn{9}{|l|}{$\begin{array}{l}\text { Submitted } \\
\text { application } \\
\text { and feels } \\
\text { that } \\
\text { premium } \\
\text { imposed is: }\end{array}$} \\
\hline High & 13 & 43.3 & 0 & 0.0 & 0 & 0.0 & 13 & 3.0 \\
\hline Affordable & 10 & 33.3 & 1 & 2.9 & 2 & $\begin{array}{c}33 . \\
3\end{array}$ & 13 & 3.0 \\
\hline Low & 0 & 0.0 & 0 & 0.0 & 0 & 0.0 & 0 & 0.0 \\
\hline Not sure & 6 & 20.0 & 0 & 0.0 & 3 & $\begin{array}{c}50 . \\
0\end{array}$ & 9 & 2.1 \\
\hline $\begin{array}{l}\text { Total } \\
\text { Respondent } \\
\text { (s) }\end{array}$ & 354 & 81.6 & 34 & 7.8 & 46 & $\begin{array}{c}11 . \\
9\end{array}$ & $\begin{array}{c}43 \\
4\end{array}$ & 100 \\
\hline
\end{tabular}

On the other hand, $61.8 \%$ of those who are unemployed and who are aged 21 to 50 have seen a land title, and just like its counterpart this group of respondents has scored way below the average for familiarity in land conversion. Only one person from this group of respondents has submitted an application for land conversion and has considered it to be affordable. As for the group of respondents who are aged 51 and above and who are unemployed, $73.9 \%$ of them have seen a land title and almost half is familiar with land conversion. Six persons from this group have submitted an application for land conversion where $50 \%$ of them are not sure of how they feel about the premium rates that have been imposed. This also shows that this group of veterans have better awareness in land conversion as compared to the unemployed youngsters. With the results of the survey questionnaire, it is evident that only $40 \%$ of the local community in Selangor is aware of land use conversion in spite of the overall $70 \%$ who has actually seen a land title. Moreover, due to less than half of the total respondents who are familiar with land conversion, it also means that only a fraction of the 
people knows about land use and what is allowed, as is stated in a land title through its land use category and express condition.

\section{CONCLUSION}

It is not surprising that the public of Petaling and Selangor are oblivious of land use and land use conversions, as these land matters do not affect them on a dayto-day basis. The only time that land conversions are of significance is when land development is required or changes in land use plans were made to boost land growth. As per land use conversion, the premium rates of the post conversion approval may seem to have sky-rocketed but in reality, it mirrors the value of the land for its intended use. These are some of the facts that may or may not reach to the public as land and property owners. With an overall score as low as $40 \%$ in the local community assessment- in terms of familiarity with land conversion, it is recommended that an awareness on land use as basic knowledge should be a priority as it may contribute to more efficient land development and town planning as a whole.

\section{ACKNOWLEDGEMENTS}

The authors would like to thank Universiti Teknologi MARA (UiTM), Universiti Teknologi Malaysia (UTM), the Petaling District and Land Office, Selangor Land and Mines Office and PLANMalaysia for allowing path in this research.

\section{REFERENCES}

Chen, J, Guo F, Wang, H, Wang Z, \& Wu, Y. (2018), Urban Land revenue and sustainable urbanization in China: Issues and challenges. Sustainability (Switzerland), 10(7), 1-12. https://doi.org/10.3390/su10072111

Chua Y.P. (2020), Mastering Research Methods. McGraw-Hill Edu. Sdn Bhd.

Hersperger, A. M., Grădinaru, S. R., \& Siedentop, S. (2020). Towards a better understanding of land conversion at the urban-rural interface: planning intentions and the effectiveness of growth management. Journal of Land Use Science, 15(5), 644-651. https://doi.org/10.1080/1747423X.2020.1765426

Hortas-Rico, M., \& Gómez-Antonio, M. (2020). Expansionary zoning and the strategic behaviour of local governments. Regional Studies, 54(3), 388-402. https://doi.org/10.1080/00343404.2019.1634801

Lim, S., Abdul Malek, J., \& Tahir, Z. (2017). Understanding Local Authority Performance Through Role Theory. Planning Malaysia, 15(4). https://doi.org/10.21837/pm.v15i4.323

Mohammad Yusup, Ahmad Fuzi Arshad, Marlyana Azyyati Marzukhi, \& Yusfida Ayu Abdullah, (2018), Temporary Planning Permission in Development Control System for Urban Development, Planning Malaysia: Journal of the Malaysian Institute of Planners, Vol. 16 Issue 3, Pg. $143-155$

National Land Code 1965 (Kanun Tanah Negara 1965) (As at 1st April 2019) (Act 828). International Law Book Services.

National Auditor Department (2019), Laporan Ketua Audit Negara: Penyata Kewangan 
Liyana Zainudin, Zaharah Mohd Yusoff, Saiful Aman Sulaiman, Jaiya Abu

Land Conversion Processes and Local Community Assessment in The District of Petaling

Kerajaan Negeri dan Agensi Negeri Serta Pengauditan Pematuhan Jabatan Negeri Selangor Tahun 2019.

Pejabat Daerah dan Tanah Petaling, U. P. T. (2019a). Senarai Semak Permohonan Penyerahan Balik Danpemberimilikan Semula Di Bawah Seksyen 204 b Kanun Tanah Negara. 1, 1-6. https://www.selangor.gov.my/petaling/resources/user_4/Senarai Semak Pemb Tanah Jan 2021/Senarai_semak_S204B-20211.pdf

Pejabat Daerah dan Tanah Petaling, U. P. T. (2019b). Senarai Semak Permohonan Penyerahan Balik Di Bawah Seksyen 197 Kanun Tanah Negara Dan Pemberimilikan Semula Termasuk Sebahagian Tanah Kerajaan Di Bawah Seksyen 76kanun Tanah Negara. 238(1), 1-5. https://www.selangor.gov.my/petaling/resources/user_4/Senarai Semak Pemb Tanah Jan 2021/Senarai_Semak_S19776-20211.pdf

Pejabat Daerah dan Tanah Petāing, U. P. T. (2019c). Senarai Semakpermohonan Secara Serentak Pecah Sempadan Tanah Dan Mengubah Jenis Kegunaan Tanah Serta Meminda Syarat Nyata Tanah Di Bawah Seksyen 124a Kanun Tanah Negara. 238(1), 1-5. Https:/Www.Selangor.Gov.My/Petaling/Resources/User_4/Senarai Semak Pemb Tanah Jan 2021/Senarai_Semak_S124a-2021.Pdf

Pejabat Daerah dan Tanah Petaling, U. P. T. (2019d). Senarai Semakpermohonan Tukar Syarat Tanah Di Bawah Seksyen 124 (1) (A) Dan (C) / 124 (1)(C) Kanun Tanah Negara. 1, 1-6. https://www.selangor.gov.my/petaling/resources/user_4/Senarai Semak Pemb Tanah Jan 2021/Senarai Semak Pem Tanah Jan2021/Latset_Senarai_semak_S124(1)(a)dan(c)S124(1)(c)-2021.pdf

Selangor Lands and Mines Office. (1998). Pekeliling Pengarah Tanah dan Galian Selangor Bilangan 4/1998, Vol. 1, Issue 071116072, p. 7. https://ptg.selangor.gov.my/index.php/database_stores/store_view_page/58/200

Selangor Lands and Mines Office. (2016). Pekeliling Pengarah Tanah dan Galian Selangor Bilangan 1/2016. Journal of Chemical Information and Modeling, 53(9), 1689-1699. $\mathrm{d} \& \mathrm{q}=$ pekeliling + ptgs $+1 \% 2 \mathrm{~F} 2016$

https://www.google.com/search?client=firefox-b-

Tian, J., Wang, B., Zhang, C., Li, W., \& Wang, S. (2020). Mechanism of regional land use transition in underdeveloped areas of China: A case study of northeast China. $\begin{array}{llll}\text { Land Use Policy, } & \text { 94(January), } & 104538 .\end{array}$ https://doi.org/10.1016/j.landusepol.2020.104538

Town and Country Planning Act 1976 (Akta Perancangan Bandar dan Desa 1976) (As at $1^{\text {st }}$ March 2018). International Law Book Services.

Selangor Land Rules 2003 \& Selangor Quarry Rules 2003 (As at $1^{\text {st }}$ June 2016). International Law Book Services.

Received: $19^{\text {th }}$ August 2021. Accepted: $25^{\text {th }}$ November 2021 